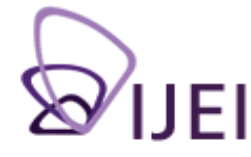

International Journal for Educational Integrity

\title{
Exploring Nigerian postgraduate students' experience of plagiarism: A phenomenographic case study
}

\author{
Stella-Maris I Orim \\ Coventry University, UK \\ S.Orim@,coventry.ac.uk
}

John W Davies

Coventry University, UK

cbx098@coventry.ac.uk

\section{Erik Borg}

Coventry University, UK

aa3096@coventry.ac.uk

Irene Glendinning

Coventry University, UK

csx128@coventry.ac.uk

Keywords: Nigerian students, study experience, plagiarism, phenomenography, IPPHEAE

\begin{abstract}
In light of the high number of Nigerian students who gain admission to overseas universities for postgraduate studies, there is an increasing need to understand their background and previous study experiences. There are few studies of the experiences or views of Nigerian postgraduate students about the concept of plagiarism. The occurrence of plagiarism in the writings of some Nigerian students who travel overseas for graduate studies, like that of other students studying in a new academic context, has become a concern in recent times. This paper aims to contribute to the current research on student plagiarism around the world by exploring the concept of plagiarism of Nigerian postgraduate students studying in a United Kingdom university. It presents results from a phenomenographic study which utilised semi-structured interviews to acquire data. In analysing the data, the views expressed by participants, the manner in which these were expressed and the context in which the views were expressed were paramount. Preconceived ideas were put aside while analysing the data, letting the data speak for itself rather than viewing the data from existing theoretical structures or presuppositions. The emerging themes were noted and comparative views of experiences were arrived at from pooling and comparing quotations across several participants. An outcome space was identified and the emerging overarching theme relating to their experiences was found to be the fear of not understanding the underlying concept of plagiarism. The students expressed deep concern about the simultaneous awareness of the need to acquire the requisite academic writing skills and utilising them, while being faced with coursework and looming submission deadlines. The results and their implications are discussed with regards to the students' adaptation and a way forward is proffered.
\end{abstract}

The International Journal for Educational Integrity is available online at:

http://www.ojs.unisa.edu.au/journals/index.php//JEI/

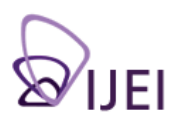




\section{Introduction}

In the last two decades plagiarism has become a widespread concern among lecturers and researchers (Gullifer \& Tyson, 2010) resulting in a large body of research exploring the concept of student plagiarism. Researchers from the USA, UK and Europe have studied this concept focusing on issues such as: students' understanding of the concept (Delvin, 2003; Shi 2004) and the reasons students plagiarise (Davis \& Ludvigson, 1995; Love \& Simmons, 1998; Park, 2003; Stevens \& Stevens, 1987; Straw, 2002) with a view to proffering ways of preventing or deterring the occurrence of student plagiarism.

However, student plagiarism in the context of Nigerian universities is largely unexplored. Over the years, with the increase of students going overseas for postgraduate studies, there is an increasing need to understand the background and previous study experiences of the students as a means of ensuring that their future study needs are met. This study focuses on Nigerian students studying at master's level in the UK as a specific case.

\section{Literature review}

Gullifer and Tyson (2010) stated that since the 1960s there has been considerable attention drawn to the issue of academic dishonesty (Aluede et al. 2006; Macdonald \& Carroll, 2006; Olasehinde-Williams et al., 2006). Plagiarism as an aspect of academic dishonesty is defined by Park as "the theft of words or ideas, beyond what would normally be regarded as general knowledge" (2003, p. 472). Park describes plagiarism both as having intent and as involving not only words but also ideas. Besides the loss of credit due the original author, Gullifer and Tyson (2010) argue that plagiarism bypasses learning and produces inadequately educated graduates whose lack of skills may pose potential threats to society through the provision of inaccurate knowledge at different levels. Furthermore, Marsden, Carroll and Neill (2005) agree that this occurrence could tarnish the image of higher education institutions and increase media scrutiny.

Though there has been a great deal of research into students' perceptions of plagiarism (e.g. Gullifer \& Tyson, 2010l; Power, 2009; Sutherland-Smith, 2005), most of the studies have been carried out in the US, Australia, and the UK. In other cases, the focus has included exploring students' understanding with the aim of devising an intervention (Breen \& Maassen, 2005; Razera, Verhagen, Pargman, \& Ramberg, 2009). Since there appears to be a variation in the level of institutional development between developed and developing countries, there might be a problem in assuming that the findings of the previous research can be generalised to students from developing countries.

Though there is little scholarly research into student plagiarism in Nigerian universities, there is a developing awareness of plagiarism in different sectors in Nigeria as shown by reports in national newspapers. Regarding the impact of institutional infrastructure on education, Majasan (1998) expressed his doubts about Nigeria being able to manage its educational sector efficiently regardless of all the available resources. He made this claim based on his assertion that Nigerian universities are still almost completely devoid of any information technology equipment or software. In line with this, Okonjo-Iweala (Edukugho, 2012), expressed surprise at what she termed the "deteriorating state of education" in Nigeria. She went on to state that there was a need to put in place mechanisms to improve the quality and facilities available for teaching as well as for research at the tertiary level.

On the issue of academic misconduct and plagiarism particularly, Onwubiko (2012) asserted that plagiarism is a very serious concern in Nigeria. Referring to the case of 
Sanusi Lamido Sanusi (the Governor of the Central Bank of Nigeria), he stated that Sanusi plagiarised his works thereby breaching copyright law. Onwubiko was displeased at the casual manner with which the case was treated and asserted that the proper thing would have been to ensure that the person so accused was sufficiently cleared by the appropriate authorities before he could go about his official duties.

A number of writers in Nigeria have connected plagiarism in universities to Nigerian youth unemployment, for example Okonjo-Iweala (Edukugho, 2012), who stated that graduates from Nigerian universities are not employable. These claims may be as a result of the observation of Dr William Udotong (Obinna, 2012) who identified plagiarism and poor writing skills as the bane of Nigeria's educational system. According to him, the Nigerian government needs to urgently address the problem of plagiarism which he said has eaten deep into the educational system of the country. He said, "The situation has become a terrible dilemma and that is why we are still where we are today. There is need to put in place technologies that could help determine originality of plagiarised works". Udotong (Obinna, 2012) further blamed the trend on the country's poor teacher to student ratio, stressing that most universities in Nigeria have a ratio of one hundred students to one lecturer.

\section{The research question}

The research question investigated by this study was: What are the plagiarism-related issues arising from the previous academic experiences of Nigerian students studying at master's level in the UK?

\section{Method}

The study was an aspect of a larger study carried out at Coventry University, UK, after obtaining ethics approval. The method adopted was phenomenography and it was used in "mapping the qualitatively different ways in which people experience, conceptualise, perceive, and understand various aspects of a phenomenon in the world around them" (Bowden et al., 1992; Marton, 1986, p. 31). This method was chosen to help recognise the variation in the previous academic experiences of the students.

\section{Design}

Semi-structured interviews were used as means of exploring the perception of these Nigerian students. The aim of the interview was to encourage the participants to reflect on their study experiences while in their various Nigerian universities and then relate those experiences in a way that they could arrive at a mutual understanding about the meanings of their experiences with the researcher.

The study focused on the Nigerian students who had just arrived in the UK for their engineering master's postgraduate study. It aimed at exploring their previous study experience and perceptions of plagiarism prior to any major intervention (e.g. plagiarism workshop, seminar or teaching) in the UK universities in which they had come to study.

\section{Participants}

Eighteen Nigerian students were selected for the semi-structured interviews from Coventry University, UK. Twelve participated in a group interview and the other six had individual interview sessions. The sample consisted of $85 \%$ males and $15 \%$ females. The participants' undergraduate studies were in 17 different universities (federal, state and private) in various regions of Nigeria. They were from two separate cohorts (2010/11 and 2011/12). 


\section{Data collection}

In agreement with the recommendation of Booth (1997), an open, deep interview was adopted as the means of data collection. Participants were asked to reflect on their experiences at their previous Nigerian universities. The interviews lasted 25 to 40 minutes. Though the researcher approached the interview session with some key questions, the interviewees were allowed to follow any line of discussion, resulting in some meaningful deviations which led to new areas for reflection.

\section{Data analysis}

The audio-recorded interviews were transcribed, and the researcher set aside any preconceived views while analysing the transcriptions. The transcripts of all the student interviews were examined in search of expressions which were relevant to the question being investigated (Marton, 1986, p. 42) with the use of Atlas.ti version 6.2. The meaning of the data was checked to be contextually correct and the excerpts were repeatedly checked to be representative of a larger section of data (Irvin, 2005, p. 114). This process continued until the modified categories arrived at appeared to be consistent with the interview data.

Once a stable outcome space was defined, an attempt was made to develop as deep an understanding as possible of what the Nigerian students had said and meant (Marton, 1994, p. 428). This was achieved through comparison of the different categories across the different students. Six categories of description were found in this study which represented the previous academic experience of the Nigerian students. For anonymity the participating students are referred to in the following section as NPS 1-18. The quotes represent views that were reinforced by more than one interviewee.

\section{Results}

Though the main results of phenomenographic study are "categories of description of the various conceptions of a phenomenon" (Ireland et al., 2009, p. 3), the technique involves more than merely listing these different conceptions. It includes identifying the conceptions and looking for their underlying meanings and the relationship between them (Entwistle, 1997). Marton stated that where some aspects are clearly more basic than others, different layers of the perceived world can be revealed (1981, p. 190). From the data collected on the previous study experiences of the Nigerian students in relation to the concept of plagiarism, six different categories were identified in relation to the:

- $\quad$ Nigerian students

- $\quad$ institution they came from in Nigeria

- $\quad$ institution they are studying at in the UK.

These categories included themes suggesting:

- $\quad$ lack of prior awareness

- $\quad$ understanding of the concept

- fear of the concept

- level of importance placed on the concept in their previous universities

- $\quad$ an institutional system of mitigating plagiarism in Nigerian universities

- $\quad$ possible ways of mitigating the concept in Nigerian universities.

These identified categories are referred to as: Lack of awareness, Perception, Fear, Importance, Institutional system and Mitigation (depicted in Figure 1): 


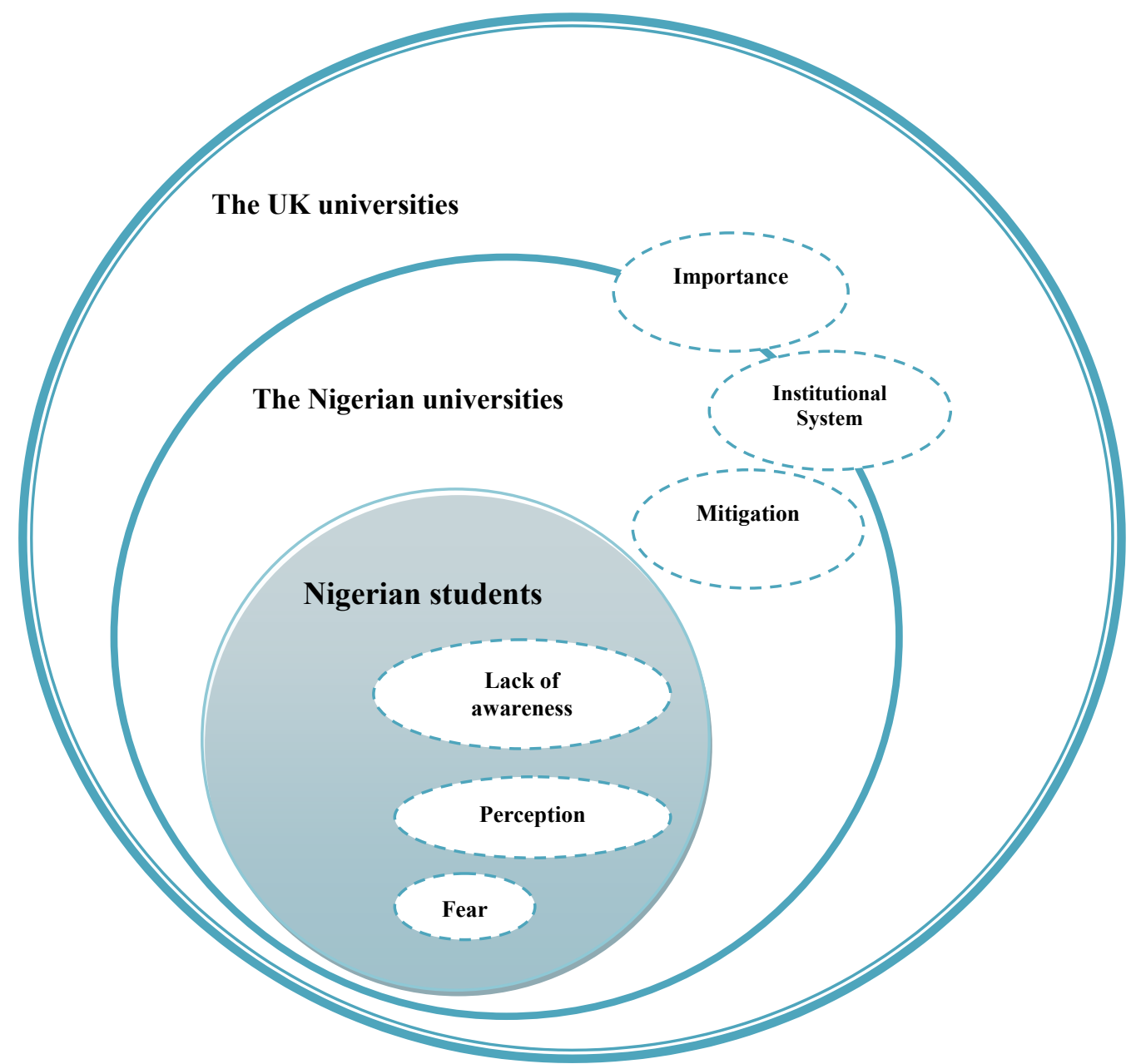

Figure 1: Categories and themes

In the next section, each of these categories is explained and illustrated in light of the data collected from the study.

\section{Category 1: Lack of awareness}

In this category, the lack of consciousness of plagiarism was conceptualised. The data from the interview sessions had some recurring themes on the experience of the students, which suggested that some of them were not aware of the concept of plagiarism prior to embarking on their studies in the UK. In these quotations, lack of awareness of plagiarism at the time of arrival for further study was cited by a number of the students though some others suggested that they were aware of the concept in their previous institutions of study.

\section{NPS 15: ...I have never heard of the word plagiarism before coming to study in} the UK...

\section{NPS 17: ...the word is truly new to me....}

A few of the students went on to express their view that being aware of plagiarism was not as a result of institutional systems in place but due to the personal effort of their lecturers.

NPS 1: I knew about plagiarism from my first degree but basically, the reason why I knew about it was not because of the structure that was put in place by the school, it was primarily because of the experience of the lecturer, my 
project supervisor who insisted on proper referencing...and it was through him I knew about plagiarism...as another word for academic theft...but it was still not clear...

NPS 11: ...It was a personal thing...not a school thing...based on the experience of the lecturer...

\section{Category 2: Perception}

In this category, the Nigerian students' perception of plagiarism was conceptualised. During the interview sessions it was observed that a number of the students had already had some form of induction. These students explained that what they understood as plagiarism was based on what they had learnt as a result of early interaction in the UK universities. From the quotes, it is observed that formulas describing plagiarism are used in an attempt at defining the concept.

\section{NPS 8: Copy directly from text book without rewording...}

NPS 13: Cut and paste...from the internet...

NPS 15: ...presenting stuff that is not yours as if it was your idea...

Furthermore, the quote of one of the participants suggests that the student may not be in full agreement with what he had been taught about plagiarism in the UK university in which he studied. This can be seen in his comment in which he still referred to it as what he had been told (...they said...).

NPS 2: ...they said it is academic stealing....

From the various views (depicted in Figure 2) which captured 'non-attribution' and outright stealing, the students had a fair understanding of the concept of plagiarism, but it appeared to be incomplete.

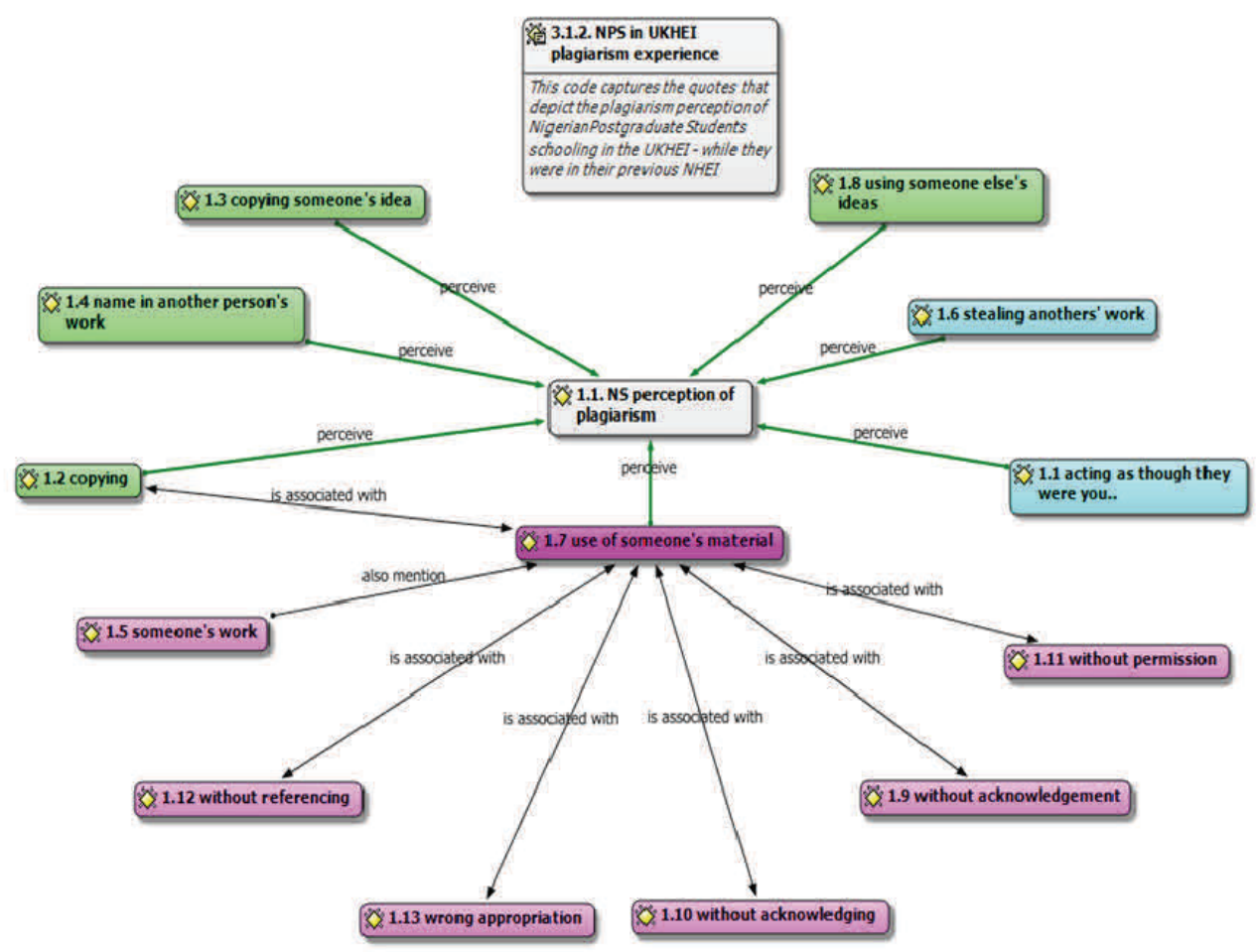

Figure 2: Plagiarism perception of Nigerian students in a UK university 
The students' views can be summed up as copying and pasting someone's work from sources (such as the internet and textbooks) without permission or acknowledgement and presenting them as though they were that of the plagiarist. They appreciated that it was not just 'work', but 'ideas' as well. Their understanding reflects more 'nonattribution' of sources and less of other forms of plagiarism such as 'patch writing', 'cheating by buying other people's work', or 'deliberate inaccurate use of references'.

\section{Category 3: Fear}

In this category, concern and fear of the phenomenon was conceptualised. In these quotes, plagiarism, which is seen as a new concept from Category 1 , is regarded as a thing to fear. The students expressed fears regarding how they would be able to acquire the requisite academic writing skills within the available timeframe during their postgraduate study. They had concerns regarding engagement in unintentional plagiarism in the course of learning the techniques of appropriate academic writing.

NPS 1: ...I now have a slogan which says...the fear of plagiarism is the beginning of wisdom...

NPS 11: ...till now I do not understand it well, I wonder... what if I mistakenly do it in my coursework...?

A look at the themes suggests students' lack of awareness while in their previous universities, but due to early exposure in the UK University, there had been development of an understanding of the implications of the concept which resulted in fear.

NPS 4: ...but we are just hearing about it...how do they expect us to learn everything about this plagiarism as we are having all these lectures, group meetings to attend and with coursework to submit...all at the same time....

As well as being concerned over the consequences arising from failure to master the skills required for proper academic writing, there was fear of financial loss of funds spent on tuition and living expenses as a possible result of exclusion from the university.

NPS 5: ...punishment here is quite costly...imagine losing your degree because of plagiarism...

NPS 9: ...after paying all that money on fees and living money in this country, they said plagiarism can stop someone from graduating...it is terrible...

\section{Category 4: Importance}

In this category, the perceived importance of the phenomenon in the Nigerian universities was interpreted. The data depicted the views of the students about the concept while in their previous Nigerian universities. It reveals the view of the Nigerian students about the institutions they came from in Nigeria and their perception of how those institutions treated the concept of plagiarism. Some of the students had not known it was a problem in the UK university because while studying in the Nigerian university, plagiarism was not considered an issue. However, due to early exposure in a UK university, students had become aware to some extent of the meaning of the concept and what penalties are attached to it, which resulted in the realisation that is considered a serious problem in UK universities.

NPS 3: ...plagiarism was not an issue... what is not an issue cannot be a problem... 
NPS 2: It was not a problem...for as long as I didn't know...but NOW, I know and it's a serious problem...

The students believed that the authorities in the Nigerian universities did not view the concept as an important one and hence did not take it seriously; this they substantiated by declaring the seeming lack of penalties associated with students plagiarising.

NPS 13: ....but they did not even take it seriously...they did not tell us or mark us down because of it...

As a result, while studying in the Nigerian universities, they felt it was not a problem. In some instances, the supervisors of the final year students saw it as important and treated it as such. But the comment on it being '...one supervisor...' suggests that not all the lecturers were actually concerned about helping students to refrain from plagiarism.

NPS 5: ....truly, what you don't know about is not a problem...

NPS 8: It was one project supervisor who is laying emphasis on it...

In these quotes, the students expressed their views that it was not regarded as much of a problem in their Nigerian universities by the staff and students. This view would be a difficult one for the students to maintain whilst studying in an institution that has a system in place for detecting and penalising cases of student plagiarism.

\section{Category 5: Institutional system}

In this category, the impact of the Nigerian university system on the academic experiences of the students in relation to plagiarism was investigated. The students expressed their views on the presence or absence of a plagiarism mitigation system in their previous institution of study. Within this category, the data suggested that there was no structural approach to the mitigation of plagiarism in their previous place of study. Students confirmed this view by describing their own practices then.

NPS 1: ...but in Nigeria, I know what I did; I just copied a particular block and put in my project and I referenced... but there were no particular standards for referencing...so a lot of things could actually affect the issue of plagiarism...

NPS 7: Copy directly from text book without rewording...presenting it as if it were your idea...There was no way of checking it because there was no software like Turnitin...

They cited their view of the lack of institutional systems in place as the reason they got away with deceptive practices. The data also revealed that in some instances when a teacher identified the occurrence of plagiarism in a student's work, there might not have been a consistent approach to penalising the student.

NPS 9: ...even when a lecturer spots instances of some copied materials, he may just ask you to go and rewrite that part of the written work...

NPS 11: ...the basic difference between this society and the one back home is the implementation of policies...

It was observed that a number of the assessments were 'examinations' and 'tests' as opposed to 'written pieces - essay or coursework' which they encountered while 
writing their dissertation. Since they had experienced two educational regimes, the students were in a position to compare. One student (NPS 14) explained that the reason that importance is attached to student plagiarism in the UK universities is because of the detection system in place.

NPS 13: During exams and all that...most of the lecturers encourage us to do exactly what others are doing ...or...do exactly as we are being taught in the class...so whereby everybody does the same thing, the output will all be the same, so we don't really talk about plagiarism and all that.

NPS 14: The issue of plagiarism in Nigeria....and I think in Africa as a whole is not as serious as it is here because of the basic difference...because the reason why so much importance is attached to plagiarism here... why you can say that somebody has plagiarised is because you have a way of ascertaining that one has plagiarised...there is a system in place...

\section{Category 6: Mitigation}

In the interviews, some students developed their thoughts on the comparison between the mitigation framework in their former Nigerian universities and that of the UK universities in which they were studying presently. The analysed data led to this category in which students discussed how plagiarism could be mitigated in the Nigerian universities.

Students discussed the importance of plagiarism in their previous universities, institutional systems in place and what was observed from comparing those with their current university. In their view, a number of the students in the Nigerian universities were not aware and those who were did not see plagiarism as an important concept because the institution failed to take ownership of dealing with the issue of student plagiarism.

NPS 1: Awareness is not the issue...even as MSc students here in UK, we are all now aware of plagiarism yet, we still attempt to do it until we turn it in and say ah...this thing has partially caught me, and I will have to rephrase this...l've done it a couple of times...

Where some of the students suggested that creating awareness amongst them was a vital step to reducing the occurrence of student plagiarism, others argued that it was merely one of the things that should be in place. They felt that there was the need for a system which not only determines the occurrence of student plagiarism, but also gives some form of constructive feedback.

NPS 2: ...awareness is a starting point, after which a structure should be put in place... and then, training programmes...

NPS 3: ...even if you create the awareness, it is never enough, there has to be something in place to check it.... a way of getting feedback that you have plagiarised...

Furthermore, they recommended good practices seen in their present UK universities that could be replicated in their previous universities to help prevent and mitigate student plagiarism. One of these practices is the institution of penalty measures. The students appeared to argue that if there was an outright penalty for the occurrence of plagiarism this would serve to reduce its occurrence. This seems to indicate the lack of a mitigation system in place in their Nigerian universities. Furthermore, it raises the need for consistent application of penalties when plagiarism is detected in students' writing. 
NPS 7: ...there has to be consequences of plagiarism in Nigeria,...like in the UK, you know if you plagiarise, you stand the risk of losing your degree, in Nigeria also, if they say, if you are caught plagiarising, this is what will happen ...

Another practice was the use of plagiarism detection software and institutional ownership of the mitigation of student plagiarism. The students perceive that, though it may be easy to try to stop the incidence of plagiarism, it is difficult to achieve. In line with this, the students appeared to believe that if there is institutional ownership of the problem and mitigation strategies introduced, some level of success could be achieved.

NPS 11: ...It's easy to say ...STOP...but more difficult to implement it....

NPS 13: ...besides the issue of awareness, there has to be something like a software.... system in place to check plagiarism...that apart, either the ministry of education or UBE [Universal Basic Education] or the NUC [Nigerian Universities Commission] has to set up modalities to address plagiarism issues...

\section{Discussion and implications}

Though the study aimed at exploring the previous study experience and perception of plagiarism prior to any major intervention (such as workshops, seminars or teachings) in the UK university in which they have come to study, the results suggest that within a month of their arrival, the students had already received some form of institutional intervention, which was reflected in their views regarding plagiarism. The following discussion will consider the major issues arising in relation to the students and their previous and present universities.

\section{About the Nigerian students}

The collected data suggests a situation in which a number of the incoming students described not being aware of anything like plagiarism prior to their arrival at the UK university for their master's study. This has not previously been explored in relation to Nigerian students, perhaps because it is an expectation of the Western educational system that students at master's level should be aware of plagiarism and should have mastery of the techniques for proper academic writing. This finding, that international students at master's level may not be aware of plagiarism, is similar to the findings of Devlin and Gray (2007, pp. 184-185) who stated that most of these students have no understanding of what constitutes plagiarism and what it entails in practice. Possible causes of the lack of awareness could be a result of the faculty in which the participating students previously studied, which was the engineering faculty. Since the predominant method of assessment was examination and very seldom by out-of-class essays with the major written task being the dissertation, the faculty/institutions probably did not see the importance of laying emphasis on the students mastering proper academic writing skills. Whichever faculty the students came from, they should have actually learnt and mastered the skills to write properly before their master's study.

Furthermore, some of those who were aware of the concept did not know it as plagiarism. A check on their perception revealed a general understanding of the concept, but further questions on what constitutes proper academic writing or 'how they will write' suggested that they did not have a full understanding of the techniques involved. This is similar to the findings of Ellery (2008, p. 514). Though her findings were in relation to first year students, she stated that they were inexperienced about what constituted plagiarism. In other studies, students indicated they were aware but 
did not mind taking the risk, thinking they were unlikely to be caught (Dordoy, 2002; Sutherland, 2004, p. 5). Furthermore, they felt that when they receive good marks, they would have better chances of finding a good job (Hayes \& Introna, 2005, p. 224).

In the group interview, a few students expressed the view that words 'belong to noone' and the internet is 'free for all'; and therefore argued that there is really no need to make a fuss about plagiarism. With further discussion, they became aware that the expression of original ideas is considered intellectual property and should not be plagiarised, just like original inventions.

A few of the students who came close to accepting the prohibition of plagiarism and the need to acquire the relevant skills, at the same time as attending lectures and submitting coursework within a limited timeframe, expressed apprehension. These students worried about 'not performing well', the 'possibility of plagiarising unintentionally', 'the penalties in place in the UK universities', 'the possibility of losing their degrees' or 'the possibility of losing their money'.

\section{Higher education institutions of learning: Nigeria and United Kingdom}

While a number of the students presented a situation of lack of awareness and institutional involvement in the mitigation of student plagiarism, some students claimed to have known the concept, but not as 'plagiarism'. They suggested that their previous universities did not do enough to prepare them appropriately with respect to acquiring the appropriate techniques for study and writing. They felt that, if writing in an academic manner had been taught, emphasised, checked with systems in place and penalties levied against plagiarism, they would have developed the requisite skills before getting to this level of study.

Data from interviews with Nigerian universities' management staff (for the broader study) suggests that the students are taught 'technical writing' in the first or second year of their undergraduate study; although there seems to be no follow-up, or checks and penalties for not applying the skills taught. The seeming lack of proper teacher enforcement or follow-up in the Nigerian universities could be as a result of the very high student-staff ratios (Obinna, 2012). Another possible reason could be that, because the students were taught in large groups in an impersonal manner, many of them might have believed that their lecturers were not committed to the disciplinary process.

Furthermore, lecturers may also be unclear on plagiarism or be unable to paraphrase appropriately, as Roig (2001) has previously noted. However, differences on the importance of the issue decrease as students' progress towards graduation (Sims, 1995). The finding of this study about the Nigerian students is similar to that of Ashworth and Bannister (1997) in the UK, where students stated that "in general, plagiarism is a far less meaningful concept for students than it is for academic staff, and it ranks relatively low in the student system of values". Though the issue of the importance of the concept varies in Nigerian universities, a review of national newspapers suggests that there is increased awareness of the seriousness of plagiarism. This is seen in the statement by Onwubiko that plagiarism is a very serious allegation (2012) and his expression of displeasure in the way the case of Sansui was handled without appropriate penalty. This supports the view expressed in the student data on how student plagiarism is handled in the Nigerian universities, but which is contrary to the comments in the press. It also suggests that the concern about the preparedness of Nigerian universities' graduates for employment is well founded, likewise the concern about educational achievements. The argument of Sims (1995) that people who admitted to cheating while at university have been found to be more likely to commit dishonest acts in employment raises concerns with respect to the integrity of the students that are being educated in Nigerian universities. 
Given that plagiarism bypasses learning and produces inadequately trained graduates (Gullifer and Tyson, 2010), there appears to be a basis for the comments of Soludo (2009) and Okonjo-Iweala (Edukugho, 2012) on the issue of employability of Nigerian graduates.

\section{Conclusion}

The findings from the analysed data clearly hold useful lessons for the UK and Nigerian universities as the participants are representatives of 17 different Nigerian universities.

The implications which can be drawn from the results are, firstly, when Nigerian students arrive at UK universities to study, they might not have heard of plagiarism. Secondly, due to the lack of awareness and minimal conception of the idea, they may not fully be able to apply their limited understanding. Thirdly, they may end up getting involved in 'unintentional' plagiarism and 'patch writing' during the early stages of their study. Fourthly, as a result of coming from institutions where plagiarism is not given prominence, in some cases, they could bring with them the same attitude that they had in their previous universities and experience surprise at how much importance is placed on it in the UK context. Hence, they may require time to adjust. Finally, due to the difficulty of learning academic writing and study skills alongside studying, they may not be able to attain their best possible performance and may fail to have the optimal study experience they could have had in UK universities.

In summary, the results suggest that in some cases, due to lack of awareness and with an educational background that did not provide an institutional system actively mitigating student plagiarism or presenting the issue of student plagiarism as important, students' understanding of plagiarism was limited, leading to fundamental academic gaps expressed as fear when faced with the requirement of the application of the skills.

Park (2003, p. 483) argued for the growing need for UK universities to develop cohesive frameworks for dealing with student plagiarism that are based on prevention, supported by robust detection, and reinforced by penalty systems that are transparent and applied consistently. This has been achieved to some extent in the UK, but there is a need to focus on assisting incoming international students to adapt to Western study culture. At the same time, Nigerian universities need to work on developing integrated and cohesive institutional policies and frameworks that are implemented across every Nigerian university. Since learning to use sources appropriately is a difficult, confusing and long process (Chanock, 2008; Davis \& Carroll, 2009; McCulloch, 2012), it is recommended that UK universities should have detailed programmes or courses which are compulsory for international master's students, in addition to one-off induction programmes. As recommended by Ellery (2008, p. 514), these universities should incorporate plagiarism training into an academic writing framework in which clear instruction will be provided.

The results from this study has found that the Nigerian postgraduate students have an inadequate understanding of plagiarism from their previous universities in Nigeria. This is in line with the views of Udotong (Obinna, 2012) that plagiarism and poor writing skills are the bane of Nigeria's educational system. The Nigerian government needs to urgently take ownership and address the problem of plagiarism, because of its historically negative impact on the country's educational system. 


\section{References}

Aluede, O., Omoregie, E. O., \& Osa-Edoh, G. I. (2006). Academic dishonesty as a contemporary problem in higher education: How academic advisers can help. Reading Improvement, 43(2), 97-106.

Ashworth, P. B. P., \& Thorne, P. (1997). Guilty in whose eyes? University students' perceptions of cheating and plagiarism in academic work and assessment. Studies in Higher Education, 22(2), 187-203.

Booth, S. (1997). On phenomenography, learning and teaching. Higher Education Research \& Development, 16, 135-159.

Bowden, J., Dall'Alba, G., Martin, E., Laurillard, D., Marton, F., Masters, G., et al. (1992). Displacement, velocity, and frames of reference: Phenomenographic studies of students' understanding and some implications for teaching and assessment. American Journal of Physics, 60, 262-269.

Breen, L., \& Maassen, M. (2005). Reducing the incidence of plagiarism in an undergraduate course: The role of education. Issues in Educational Research, 15(1), 1-16. Retrieved July 2, 2011, from http://www.iier.org.au/iier15/ breen.html

Chanock, K. (2008). When students reference plagiarised materials - what can we learn (and what can we do) about their understanding of attribution? International Journal for Educational Integrity, 4(1), 3-16.

Davis, S. F., \& Ludvigson, H. W. (1995). Additional data on academic dishonesty and a proposal for remediation. Teaching of Psychology, 22(2), 119-121.

Davis, M., \& Carroll, J. (2009). Formative feedback within plagiarism education: Is there a role for text-matching software? International Journal for Educational Integrity, 5(2), 58-70.

Delvin, M. (2003). The problem with plagiarism. Campus Review, 12(44), 4-5.

Devlin, M., \& Gray, K. (2007). In their own words: A qualitative study of the reasons Australian university students plagiarize. Higher Education Research \& Development, 26(2), 181-198.

Dordoy, A. (2002). Cheating and plagiarism: Student and staff perceptions at Northumbria. Proceeding of Northumbria Conference July 2002. Educating the future. Retrieved January 2, 2012, from http://www.jiscpas.ac.uk/images/bin/ AD.doc

Edukugho, E. (2012). Challenge of producing unemployable graduates. Vanguard. Retrieved January, 2012, from http://www.vanguardngr.com/2012/07/challengeof-producing-unemployable-graduates/

Ellery, K. (2008). Undergraduate plagiarism: A pedagogical perspective. Assessment \& Evaluation in Higher Education, 33(5), 507-516.

Entwistle, N. (1997). Introduction: Phenomenography in higher education. Higher Education Research \& Development, 16, 127-134.

Gullifer, J., \& Tyson, G. A. (2010). Exploring university students' perceptions of plagiarism: A focus group study. Studies in Higher Education, 35(4), 463-481.

Hayes, N., \& Introna, L. D. (2005). Cultural values, plagiarism and fairness: When plagiarism gets in the way of learning. Ethics and Behaviour, 15(3), 213-231.

Ireland, J., Tambyah, M., Neofa, Z., \& Harding, T. (2009). The tale of four researchers: Trials and triumphs from the phenomenographic research specialization. Available online from: http://eprints.qut.edu.au/20457/1/ c20457.pdf

Irvin, S. (2005). Parent conceptions of their role in early childhood education and care: A phenomenographic study. Doctoral thesis, Queensland University of Technology, Queensland, Australia. Available online from: http:// eprints.qut.edu.au/16165/1/Susan Irvine Thesis.pdf

Love, P. G., \& Simmons, J. (1998). Factors influencing cheating and plagiarism among graduate students in a college of education. College Student Journal, 32, 539-551. 
Macdonald, R., \& Carroll, J. (2006). Plagiarism: A complex issue requiring a holistic institutional approach. Assessment \& Evaluation in Higher Education, 31(2), 233-245.

Majasan, O. (1998). Qualitative Education and Development. Ibadan: Spectrum Books.

Marsden, H., Carroll, M., \& Neill, J. T. (2005). Who cheats at university? A self-report study of dishonest academic behaviours in a sample of Australian university students. Australian Journal of Psychology, 57(1), 1-10.

Marton, F. (1981). Phenomenography: Describing conceptions of the world around us. Instructional Science, 10, 177-200.

Marton, F. (1986). Phenomenography: A research approach to investigating different understandings of reality. Journal of Thought, 21, 28-49.

Marton, F. (1994). Phenomenography. In T. Husen \& T. N. Postlethwaite (Eds.), The international encyclopaedia of education: Volume 8 (2nd ed.) (pp. 4424-4429). Oxford, UK: Pergamon.

McCulloch, S. (2012). Citations in search of a purpose: Source use and authorial voice in L2 student writing. International Journal for Educational Integrity, 8(1), $55-69$.

Obinna, C. (2012). Nigeria: Plagiarism, bane of Nigeria's Educational Devt - Provost. Vanguard, 20 September 2012. Retrieved December 18, 2012, http:// allafrica.com/stories/201209200813.html

Olasehinde-Williams, O. (2006). Instituting academic integrity in Nigerian universities: Psychological perspectives of morality and motivation. Journal of Sociology and Education in Africa, 4(2), 153-165.

Onwubiko, E. (2012, August 13). Plagiarism: The story of Sanusi and Zakari. Modern Ghana News Retrieved December 14 2012, from www.modernghana.com/ news/411227/1/plagiarism-the-story-of-sanusi-and-zakaria.html

Park, C. (2003). In other (people's) words: Plagiarism by university students-literature and lessons. Assessment and Evaluation in Higher Education, 28(5), 471-488.

Power, L. G. (2009). University students' perceptions of plagiarism. Journal of Higher Education, 80(6), 643-662.

Razera, D., Verhagen, H., Pargman, T. C., \& Ramberg, R. (2009). Plagiarism awareness, perception and attitudes among students and lecturers in Swedish Higher education. Retrieved December 17, 2011, from: http:// www.plagiarismadvice.org/documents/conference2010/ papers/4IPC 0069 final.pdf

Roig, M. (2001). Plagiarism and paraphrasing criteria of college and university professors. Ethics and Behaviour, 11, 307-324.

Sims, R. L. (1995). The severity of academic dishonesty: A comparison of faculty and student views. Psychology in the Schools, 32(3), 233-238.

Shi, L. (2004). 'Textual borrowing in second-language writing'. Written Communication 21(2), 171-200.

Soludo, C. C. (2009, February 25). $80 \%$ of Nigerian graduates are unemployable. Nigerian Tribune.

Stevens, G. E., \& Stevens, F. W. (1987). Ethical inclinations of tomorrow's managers revisited. Journal of Education for Business, 63(1), 24-29.

Straw, D. (2002). The plagiarism of generation 'why not?'. Community College Week, 8 July, 14(24), 4-7.

Sutherland-Smith, W. (2005). Pandora's box: Academic perceptions of student plagiarism in writing. Journal of English for Academic Purposes, 4(1), 83-95.

Sutherland-Smith, W. (2004). The right to own: Intellectual property, plagiarism and international students' academic writing . Paper presented at the American Association of Applied Linguistics, 1- 4 May, 2004, Portland, Oregon, USA. 


\section{About the authors}

Stella-Maris I Orim MSc, MCM, BEng, PMBCS, FHEA, is a current doctoral student and a National Teaching Fellow of the HE Academy. Her research centres on the investigation of student plagiarism in Nigerian universities from the student, teacher and management staff perspective. She is exploring the possibility of developing a student plagiarism mitigation framework that can be used across Nigerian universities as a consistent approach to the mitigation of student plagiarism. She has worked as a Research Assistant on the Impact of Policies for Plagiarism in Higher Education across Europe (IPPHEAE) Project and is presently working in Coventry University, UK.

John W Davies MSc, MA, PhD, CEng, FICE, FHEA, is Professor of Civil Engineering within the Department of Civil Engineering, Architecture and Building at Coventry University. He has 30 years' experience as an academic, following eight years practising as a civil engineer. He was Head of Department at Coventry for nine years up to 2010 . He has a wide range of interests in engineering education. He is Editor of Engineering Education - A Journal of the Higher Education Academy. In 2012 he was made a National Teaching Fellow of the HE Academy.

Erik Borg is a senior lecturer at Coventry University's Centre for Academic Writing, where he teaches undergraduate and master's level modules on writing and research. His research, which centres on research into the nature of writing in a rapidly changing communication environment, investigates intertextuality and multimodal communication. He has published widely, including recent articles in Assessment and Evaluation in Higher Education, The Journal of Writing in Creative Practice, and Teaching in Higher Education.

Irene Glendinning is Academic Manager for Student Experience for the faculty of Engineering and Computing at Coventry University. She is Principal Investigator for the Lifelong Learning Project 'Impact of Policies for Plagiarism in Higher Education Across Europe' (IPPHEAE 2010-2013), funded by the European Commission. Her research interests include quality assurance, student diversity and equality, pedagogy, student employment and employability. She has been an academic in higher education since 1990, with extensive experience of programme management covering a range of disciplines and lecturing in computer science. Earlier in her career she was a systems analyst and computer programmer and she also taught mathematics, IT and computing at secondary school level. 